\title{
Religious tourism and pilgrimage at Prislop Monastery, Romania: motivations, faith and perceptions
}

\author{
Mădălina Giușcă* \\ University of Bucharest, Romania
}

Romania has a large number of churches, monasteries or places of worship as well as a great diversity of spiritual and religious destinations, thus explaining the development of forms of tourism such as religious tourism and pilgrimage. Previous researches confirm that in Romania religious tourism and pilgrimage has been on an ascending trend, Prislop Monastery being one of the most visited religious sites. A delimitation between the two types is difficult to make because of the different valences they have. This study starts from personal field observations, aiming to explore, based on qualitative methods, the motivations, perception or religious practices in the area, trying to differentiate distinct categories of visitors. The context of visits, the frequency, motivations and practices related to religious tourism or pilgrimage represented the basis of the analysis, relied on semistructured interviews. The results showed that the motivations were mixed, starting from religious practices rigorously performed, to simple visits that were made out of curiosity and aroused by mass-media.

Key Words: religious tourism, pilgrimage, motivations, perceptions, pilgrim, tourist, Prislop Monastery, Romania

Article Info: Received: February 13, 2020; Revised: May 1, 2020; Accepted: May 11, 2020; Online: May 23, 2020.

\section{"Correspondence address}

Address: Doctoral School "Simion Mehedinti”, Faculty of Geography, University of Bucharest, N. Bălcescu Av., no. 1, 4th floor, room 410, Bucharest, 010041, Romania. Phone: +40760.31.68.69|Email: ge.madalina@yahoo.com

(C)2020 Human Geographies; The authors

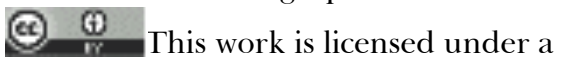

Creative Commons Attribution 4.0 International License. DOI:10.5719/hgeo.2020.141.9 


\section{Introduction}

Pilgrimage and religious tourism are two concepts which need to be clarified in order to understand the context approached in this study. Religious tourism and experiences that lead to this kind of tourism were studied from different perspectives. From the sociological point of view, the experiences and behaviours of tourists as integrated into pilgrim experiences has been argued; this has been a revolving element for all academics (Reader, 1993). A distinguishing factor among tourists and pilgrims is that the pilgrim can be identified as someone that is led by a desire for change and the belief that this can be found at a pilgrimage site (Reader, 1993, based on Turner, 1972). To add even more ramifications to the differences between tourists and pilgrims, a growing number of spiritual and religious destinations opening up to visitors, developed in principal religious centres, having a rich historical and artistic heritage. The real motivation that stands behind visiting heritage/pilgrimage sites is what makes visitors decide to go to destinations - the binomial of religion and heritage are expanding.

The basis of cultural tourism stands in the exploration and attendance in new and profound experiences of an aesthetic, intellectual, emotional or psychological nature (Reisinger, 1994). Cultural tourists can learn about the culture of a specific destination and life experiences related to a targeted culture in different ways, depending on the forms of culture they consume and understand (Richards, 2007). Cultural tourism is becoming an experiential product in which visits are judged according to all the attributes of the resource, not only to their cultural value (Richards, 2018).

The touristic objective that constitutes the basic cell of the tourist potential of a territory is the elementary unit of the landscape. The tourist objectives with religious connotations determine the practice of religious and pilgrimage tourism - the form of tourism with specific features keeping the same structure of tourism in general (Whelan, 1991). In the modern and contemporary era, the emphasis on the structure and dynamics of tourist flows shifts from the attractive values of the natural setting to the anthropic ones or vice versa. A constant of religious objectives is constituted by the architectural, pictorial, and functional artistic values, as well as by the religious activities specific to cults and practitioners (Cocean, 2004).

The new tourist models of mentality, sensitivity and interest enjoy higher levels of quality of life and education, as well as a broad life experience with more leisure time and easy access in means of communication and transportation (MacCannell, 1976). However, this context is valid in modern societies. This type of tourist acknowledges the relationship between quality and price and demands more environmental and cultural authenticity. Nowadays it is more consistent to link the concept of tourism with cultural components, which include segments whose features and motivations differ considerably - from touring activities to strictly cultural tourism - which converge in the use of goods, places or cultural customs (Crespi \& Planells, 2003). The relationship between religious tourism, conventional tourism and pilgrimage tourism displays the fact that religious 
tourism fills at the interference between eminently sacred activities, represented by pilgrimages and those specific to tourism in general (Martinez-Cardenas, 2010).

The development of contemporary tourism and market research has led to the conclusion that cultural, religious and pilgrimage and nature-based tourism has an upward trend, by attracting many historical, cultural sites: castles, fortified churches, fortresses, monasteries, hermitages, museums, memorial houses. Thus, it is necessary to re-evaluate the material base - as a fundamental constituent part of the tourist heritage (Ielenicz \& Comănescu, 2006). Pilgrimages are not only "the simplest form of religious tourism" they are the most famous tourist events with religious content and "spiritual tourism" is defined as a way of travel with an exclusively religious motivation (Martinez-Cardenas, 2010).

Religious tourism is the form of tourism that involves visits to places of worship, unique tourist attractions through their religious edifices (Rinschede, 1992). At the same time, mixed/alternative forms such as tourism pilgrimage developed, entailing, in addition to religious practice the access/use of accommodation infrastructure (Gheorghilaș, 2014). However, all these forms, pilgrimage, tourism pilgrimage, and religious tourism rely on the existence of religious edifices and destinations that have developed and have become very popular in time. Also, they require travelling to these destinations, individually or in an organised group, using certain means of transport. Moreover, pilgrimage tourism also implicates practices of religious tourism but with a certain regularity of space and time, at destinations very well known. According to studies, the places of pilgrimage near homes are not necessarily the most visited, and they choose to make these religious trips even at long distances in order to have a close bond with the holy (Turner, 1973).

Religious tourism has evolved, but still retains features of the actual pilgrimage. It implies a high degree of culture and training that facilitates the appreciation of cultural-religious objectives in terms of construction, architecture, value, spiritual significance, and content. There are still pilgrimages occasioned by the religious traditions of different countries or the specific occasional ones (relics, miracle-working icons). In all these manifestations, the essential pillar remains the religion whose manifestations are in continuous change and diversification (Noppen \& Morisset, 2003). This way, it is essential to note that not all who are participating in religious tourism have religious reasons or motivations to do so. The term 'pilgrimage' is usually applied to many activities which are not explicitly religious neither in motivations or type, but rather are part of broader experiences or routes. Regarding the route, it is necessary to take into account the pilgrimage site itself, as tourists situated in that kind of locations can easily be mistaken as pilgrims (Reader, 1993).

In Romania, there are approximately 16,000 churches and 556 monasteries that have been inventoried in previews studies (Giușcă et al. 2018). Improving the quality of life, access to various sources of information and increasing the level of culture, explains the desire of Romanians to know the religious phenomenon by going directly to sources. According to the last census (2011), whose data were 
published by the National Institute of Statistics (INS, 2013) show that $85.7 \%$ of the Romanian population declared themselves part of the Christian-Orthodox religion. In these conditions, it can be stated that most of the interviewees belong to this religion with specific practices.

Romania, in the first decade of the post-communist transition, recorded a significant religious revitalisation where religious practices became increasingly common. The phenomenon of pilgrimage involved several complex phenomena, with geographical, psychological, anthropological, sociological, and theological dimensions. The industrialisation, modernisation, urbanisation that has taken place in European countries in recent centuries has led to a diminution of the role that religion plays in social life. Since this diminution of the influence of religion in social life, in the last twenty-five years, the phenomenon of pilgrimage has developed majorly in Romania. At the beginning of the millennium, Romania was one of the most religious countries in Europe, both in terms of religious practice and in terms of faith and shared values (Voicu, 2007). After the fall of the communist regime, the coordinates of the religious field have changed. Real religious liberalisation has taken place, imposed restrictions have been lifted, new religious movements have taken place, monasteries were built, and pilgrimage gained significant valences in the Romanian space, and is considered a form of cultural tourism (Gillet, 2001). The evolution of the Romanian society inevitably led to a change in the position of the population towards the religious phenomenon, intertwined with the touristic activity. Comparing to communistera, when these practices were dimmed, after 1990, on the background of the transformations in society, one can notice a steady increase in religious practices and a revival of pilgrimages as well as religious tourism (Giușcă et al. 2018).). Thus was born the religious and pilgrimage tourism, as an expression of the fact that the Romanian people are people whose religious faith has lasted throughout its troubled history.

In a Europe that is increasingly turning away from religion, Romanians not only are among the most faithful inhabitants of the continent, but the quantitative data demonstrate a religious revitalisation on several dimensions of religious involvement (Voicu, 2007). According to the Global Index of Religion and Atheism (GIRA), published by WIN-Gallup International, in $200585 \%$ of Romanians declared themselves religious; below the level in Kenya (89\%), but above that in Pakistan (78\%). Seven years later, Romania surpassed Kenya, Iraq and Afghanistan and ranked 6th in the world, with $89 \%$ of the population selfidentifying as "religious" (GIRA, 2012). A large number of priests, the enormous confidence and trust that the population has towards the institution of the church could serve as indicators when measuring the degree of religiosity of Romanians.

Romania being a predominantly Orthodox country with numerous places of worship, which allowed the development of religious and pilgrimage tourism, needed an inventory of holy places. The choice of the setting in which this study has taken place was not coincidental. Previous research developed in the religious tourism field proposed a model to evaluate the tourist valences of religious edifices in Romania as well as the degree of their valorisation (Giușcă et al., 2018). 
There were identified all the monasteries across Romania (556) established a database where characteristic elements that belonged to three dimensions were analysed. Scores were grated for the subdivisions of each dimension according to established criteria, from a scale elaborated. According to the total score obtained, each religious edifice analysed held a particular position in the national hierarchy. Prislop Monastery reached the highest score (from a total of 556 monasteries across Romania) being considered the most important religious edifice in Romania. These previous researches represent the starting point for the present investigation explaining the reason to choose this place, as the study area. The main objective of this exploratory study is to identify the motivations and perceptions of visitors based on the general reason of their visit and the various practices that they undertake on-site, which are more or less related to faith, outlining some typologies.

\section{Study area}

Prislop Monastery is located in the western part of Romania, in a hilly region surrounded by the Carpathian Mountains (Figure 1). The monastery complex is built at an altitude of 580 meters, in a meadow surrounded by abundant green space, followed by hills covered with forests of oak, beech, hornbeam, pine, spruce, birch and shrubs. For almost seven centuries, it has been one of the most important Orthodox religious establishments in Transylvania.
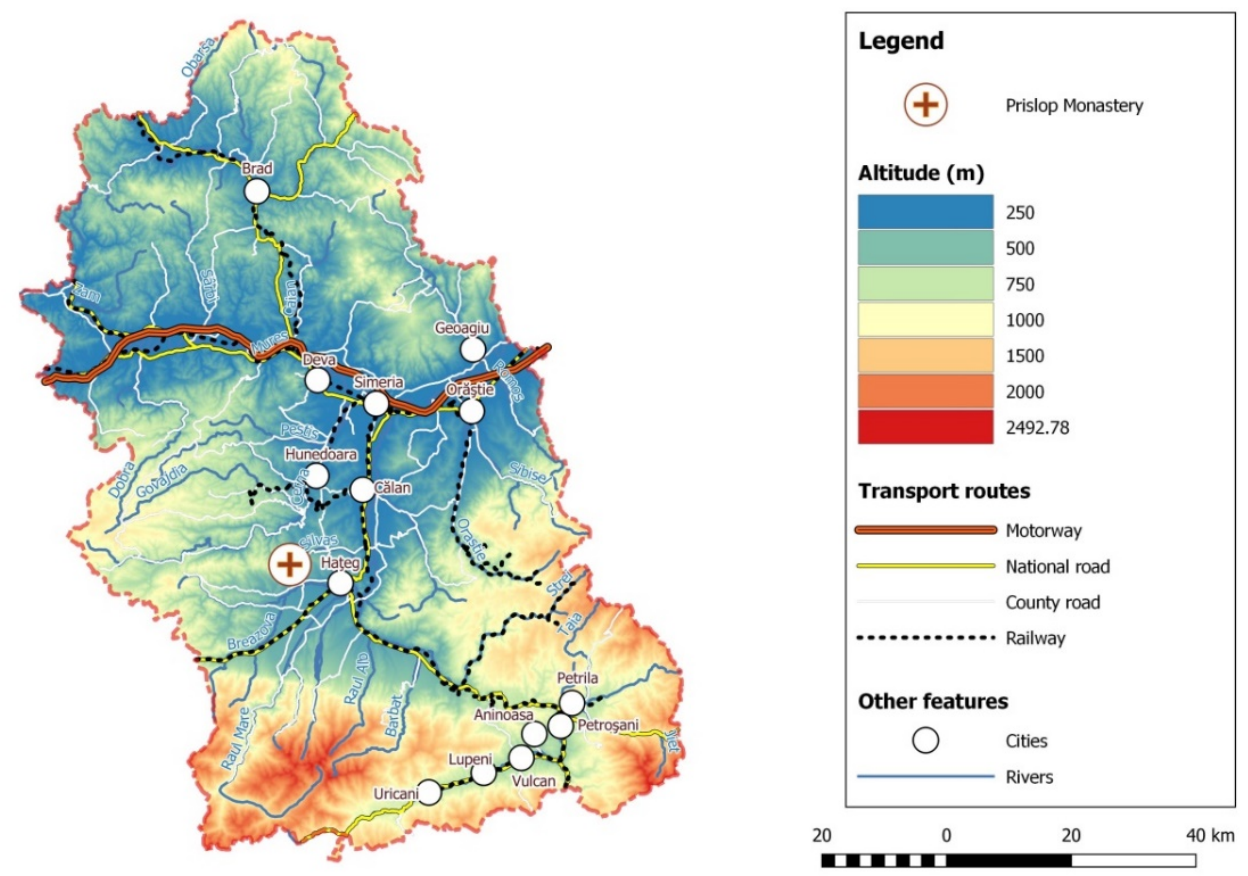

Figure 1. The Prislop Monastery location in Romania Source: Map processed in ArcView; author: Mădălina Giușcă, 2020 
In addition to the beauty and uniqueness of the monastery, built by the efforts of the three great founders (Father Nicodim, Miss Zamfira and Father Arsenie Boca), the Prislop Monastery attracts like a magnet thousands and thousands of visitors from all over the country, through a symbol: Tomb of Arsenie Boca. Father Arsenie Boca, born in 1910, lived here for a period, being abbot (1950), church painter and theologian. His life was full of events and obstacles, but the way he passed all transformed him a model among Orthodox believers. After his death, in 1989, people continue to come to pray to his tomb, stating that his power turns into miracles. That is why he is considered a saint. The Arsenie Boca become a phenomenon, determining massive pilgrimages, with the resizing of the Prislop Monastery, but also with socio-economic implications on the Land of Hațeg - the area that hosts the place of worship considered as generating miracles. The tomb of Father Arsenie Boca from Prislop Monastery is considered now one of the significant places of pilgrimage in Romania. The monastery is relatively easy to reach, and the road offers beautiful views, mostly on the top of the hills with a wide-open horizon across the depression of Hateg.

The first documentary attestation of the Prislop Monastery dated from 1360. Located $200 \mathrm{~m}$ from the current church, the place "La Mănăstirea Bătrână" represents a testimony of the existence of another monastery on that place, built of wood. The Prislop Monastery in its current form dates from the end of the XIV century, being built of stone, in triconch plan, with the tower on the nave elements specific to the churches in Wallachia. For 150 years, no documents have been written attesting to the spiritual life of this monastery, but it is considered that it continued from the words of the believers. After a long period of a total absence of monastic life, the nuns of Prislop Monastery, under the artistic and spiritual guidance of Father Arsenie Boca, managed to raise its spiritual, artistic and household prestige, so that today the monastery presents itself as a valuable medieval monument and an example of the spiritual life that attracts believers and tourists from the country and abroad.

Along with the other great Romanian Transylvanian monasteries, Prislop Monastery maintains an important place in the cultural and ecclesiastical life of Romanians in the intra-Carpathian territories, being a symbol of Romania's unity and continuity.

\section{Research methods and data}

The phenomenon of religious tourism and pilgrimage that gained importance in media framed the idea of this study. Bibliographic information, documents, field observations and primary data constituted the basis of this exploratory research. The collect in-depth information on the visitors, both, tourists or pilgrims, we used the survey method. Usually, exploratory studies start from a large number of indicators, but along the way, insignificant ones are eliminated; according to the analysed and pursued objective, only relevant indicators are retained (Cauc, 2004). 
The study tried to identify and evaluate the motivations and perceptions of the religious visitors both practitioners and tourists to the concepts of pilgrimage - faith (and the connection between them) and religious tourism and to outline the profile of two categories, as resulted from interviews. To highlight the motivations and the perception of the visitors, a survey consisting of semistructured interviews with both open and closed questions was set-up. We used a probabilistic sample of 100 respondents, all Romanians, interviewed face to face, during a field trip to Prislop Monastery in July and September 2019. This step was the basis of an interdisciplinary approach to the subject of religious tourism and pilgrimage in the context of today's society.

Primary data and in-depth information collected semi-structured interviews also served to outline the categories of visitors. The subject was analysed by using qualitative methods for deepening qualitative results to the detriment of only quantitative ones due to the difficulty to measure the religiosity of people by using standardised questionnaires that contain closed questions only. The use of semistructured interview allowed a more flexible analysis of the phenomenon. One of the methods used was the participatory observation method, as it has been considered that it is an essential step of any process of implicit knowledge of any scientific research. This scientific method respects the rules of the research, and it is based on a concrete study objective, on detailed planning, and which has a research purpose, being recorded continuously. Through this method, it was directly observed the studied phenomena, using appropriate tools from which were obtained empirical conclusions with truth-value for the chosen topic. To formulate specific questions, the answer to which should provide information as close as possible to reality, Garfinkel's method of ethnomethodology was studied, as phenomenology in daily life. This method was invented in 1940 and systematised in 1967. Respondents are asked to answer questions such as "what do you mean by ...?". Thus the results obtained surprise a less stressed dialogue partner, with confidence and openness to the interviewer, which leads to effective communication and sincere answers (Garfinkel, 1967).

The sampling framework did not take into account patterns that respect the population structure, because not all age groups participate in pilgrimages, pilgrims are mostly female, and most of them are matures/ elderly.

The difficulties in applying the interviews were inherent. The main difficulties were: the lack of cooperation of some potential subjects, mainly young people and the reluctance of others to answer; the interruption of the rhythm of religious rituals practised by pilgrims, sometimes the halo effect of questions is present in the case of a group, the supremacy of one member intervenes in answering within the families, the elderly are full of solicitude sometimes straying from the subject to the questions related to faith, some respondents get stuck; pilgrims stay grouped and tend to give answers in the same type, the religious spirit can prevent them from answering (near the Tomb of Arsenie Boca).

Research hypotheses start from the premises that all participants have a specific relationship with divinity; as well, we supposed that each visitor has a more or less motivation related to religious practices or faith. Socio-demographic variables (age, gender, level of culture, occupation, income, marital status and number of children) highlighted the profile of the participants. 
Table 1. Demographic variables

\begin{tabular}{lc}
\hline \multicolumn{1}{c}{ Whole sample } & $\%$ \\
\hline Gender & 40 \\
Male & 60 \\
Female & \\
Age & 13 \\
$18-25$ & 4 \\
$25-35$ & 37 \\
$35-50$ & 46 \\
>50 & \\
Area of origin & 36 \\
Rural area & 64 \\
Urban are & \\
Education & 15 \\
Elementary School & 41 \\
High School & 44 \\
Higher Education & \\
Occupation & 67 \\
Employed & 25 \\
Retired & 8 \\
Non-employed & \\
Marital Status & 79 \\
Married & 21 \\
Single & \\
Children & 24 \\
Without & 42 \\
1 Child & 34 \\
2 or more & \\
\hline Source:Primary research & \\
\hline
\end{tabular}

Source: Primary research

The socio-demographic profile of respondents was outlined for both pilgrims and religious tourists. Most of the visitors are over 50 years, regarding gender mostly are women who are married and have one child (Table 1). The level of education of the respondents provided a complete picture of the population's access to different categories of tourist services, including religious and pilgrimage, and helped assess differences in faith, religious beliefs, and the real reason for practising religious tourism. From the level of education point of view, most of them have university degrees. From this, we deduce that the degree of culture increases religiosity through a higher capacity to understand the religious phenomenon and an increased curiosity. Regarding their occupation, most of the visitors are employees. Population income data did not provide an accurate measurement of their level, as respondents were not entirely honest. However, one can assume that participants in any form of tourism fall into the category of those with medium and high incomes. Low-income families, although faithful, cannot afford to practice any type of tourism, paying transportation costs, accommodation, meals. This theory reinforces the answers to the previous subject, the one regarding occupation. Regarding the environmental origin of the participants, the majority of them come from urban areas (Table 1). A possible 
explanation would be the lack of time/income of those in rural areas, compensated by religious practices at home or in churches in the village

The interview grid was structured into two sections. The first one included questions regarding trip information - the kind of transportation used, people who accompany, the time spent at the site, the frequency of the visits, how the trip was made (in an organised group or individual), the kind of sources of information used when going in such trips and if some opted for a guide or not. The second section targeted questions that outlined the purpose and motivation that drawn visitors in such trips, the grade of religiosity and their perception about the concepts of pilgrimage and religious tourism.

There were conducted individual interviews, and then the survey dressed a final form. The use of open-ended questions highlighted the objectives of the questions. The data collected on the field has been processed and centralised in Microsoft Office Excel 2010. The cartographic representation used was made in ArcGIS 103.1 and ArcView. For the open questions, it was used a codification after a single word used by respondents (mainly the first word expressed) considering that other words that bring explanations are determined by an idea, constituting post reflexive semantic effects. Quantification is based on synonymy because it expresses precisely the basic notion. In closed questions, the choices of subjects were analysed and transformed into percentages.

\section{Results and discussions}

The tourist potential of the territory, regardless of the surface, represents the capacity of the particular place to constitute itself in a tourist destination, being a result of the natural and the anthropic factors on the environment (Snack, 1976). Depending on this, the type of tourism that can be practised in that location is delimited. Prislop Monastery being a religious destination, it is part of this type of tourism along with pilgrimages. Both religious tourism and pilgrimages have certain implications (Snak, 1976). Participants must have a specific behaviour, respect the rules imposed, understand the language used by places of worship and express their faith.

Many researchers in the field of tourism have analysed the phenomenon of religious tourism vs pilgrimage and, based on the findings of surveys, developed a scale of the characteristics of visitors to the holy sites according to their importance and lack of interest in tourism (Collins-Kreiner \& Cliot, 2000). The interview applied at Prislop Monastery followed the same principles that analysed important aspects that linked socio-demographic variables to the context of the visit and motivations and perceptions. Arsenie Boca, represents without doubts, the catalyst for this site, for both pilgrims or visitors; his miracles, his story and not less important, the mass-media coverage that he enjoys, are contributing to its fame. People use the name of Arsenie Boca and not the name of the place to locate them. Most often, the name of the monastery is eluded, all visitors 
mentioning that they come to Father Arsenie Boca, and not to the monastery (that holds the grave and the history related to Father Arsenie Boca).

\section{Visit context, frequency and resources}

In order to explore the two categories - religious tourist and pilgrim according to their motivations and perceptions, it is essential to understand the context in which the trip to the chosen location was made, in this case, Prislop Monastery. Pilgrimages, both in history and in specific bibliography, are described as being made in large groups, using the same way to reach the destination, which is most of the time by foot. The basic idea behind this action is communion, the connection between people and getting out of the comfort zone. In the case of the present study, it was found a considerable number of people who prefer to use their own means of transport $(75 \%)$ in the detriment of the collective ones (Table 2.). Very rarely, people are seen alone, most of them are accompanied by family members or friends, coming from urban areas. Using a personal car is preferable to another type of transport for convenience, due to health problems and for lower costs (Photo 1). People tend to travel on their own (76\%) - regardless of the distance, they come from, and not in organised groups moderated by a guide, because they want to spend their time and be as flexible as possible, not depending on a group, as seen in Table 2. Among those interviewed were people who do not fit into this trend but cannot be categorised as authentic pilgrims either.

During field observations, coaches with people visiting the monastery could be observed (Photo 1). Among them were only adult women, who travelled alone, their primary purpose being the religious one. They had come together with the priest or deacon of the church of which they belong - mainly small towns or rural areas, from there also taking the necessary information about the trip. They were explicitly dressed, with dark clothes that cover the body as much as possible and with their heads covered. The priest took the place of the guide, and together with him, they visited the monastery. They had to respect a specific program and time allotted to visit and pray. The groups were made up exclusively of women, and the only man in the group being the priest and the driver. It is known that in most societies, women are more religious than men, based on studies in this direction (Hackett et al., 2016; Stark, 2002; Trzebiatowska \& Bruce, 2012; Walter \& Davie, 1998). Those who come to Prislop Monastery in organised groups cannot be considered with less financial resources than those who choose to travel on their own, but it can be assumed that they have stronger religious beliefs and are found in such groups. Religious education makes the woman to visit places of worship, praying for all family members as one of the respondents stated:

\footnotetext{
"I came to pray for all family members so we can have a blessed and healthy year...since my first visit I saw changes and continued coming yearly" (Woman, 54 years, Dressmaker, Toplita)
} 


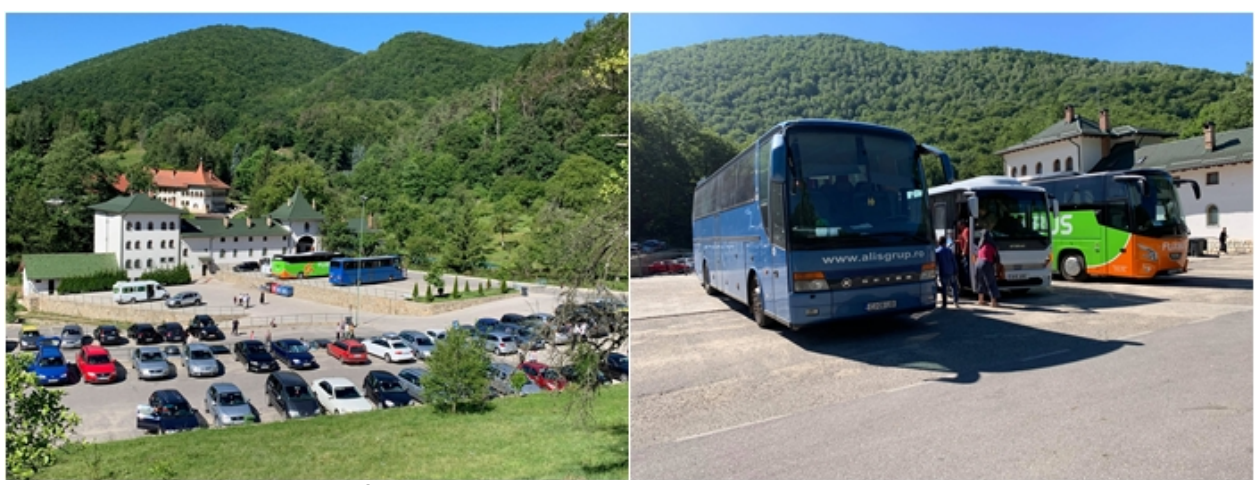

Photo 1. The parking lot of Prislop Monastery

Author: Mădălina Giușcă, July 2019

Trips to Prislop Monastery often take place in close relation to important religious events but are not limited to those, and are undertaken mainly once a year (Table 2). This indicator, which refers to the frequency of visiting the monastery, should not be confused with the frequency of visiting places of worship in general. A possible explanation would be that the Prislop Monastery is at a greater distance from places they live than other places of worship, and yet the interviewees visit it at least once a year $(52 \%)$.

When analysing the time spent on the whole trip, the proportion was balanced. People with families choose to stay a couple of days in the surroundings (68\%), because of their flexible schedule, while those travelling in organised groups came only for a day (Table 2). Families are composed of all ages where some came from greater distances while some come from close proximity but need a few days of rest in such a setting. This highlighted the fact that people know their priorities, take into account the time they have and the material resources.

"I come here in summer when I can take free time from work. I have a stressful job, and I come for a couple of days to spiritually recharge. Simply the place itself gives you good energy" (Man, 38 years, Programmer, Bucharest)

In the modern age, people tend to use technology in any context, to get information's mainly from online sources (48\%) or friends and family, eliminating the need for physical guidance, this being an explanation for the fact that people do not reach for a guide (87\%) when undertaking such trips, (Table 2) considered as exceptions those who came in church-related groups.

"We heard from Father Arsenie Boca from TV a few years ago, in a documentary, but never thought of coming here. Some friends insisted on stopping here in our way. We are impressed by the beauty and the calm that wraps the location, surely we will come again." (Woman, 42 years, Bookkeeper, Slobozia)

\section{Motivations, faith and perception}

Religious motivation is, besides a religious belief, a sphere of religiousness, which has been extensively investigated (Schaefer \& Gorsuch, 1991). 
Table 2. Primary results of the interview

\begin{tabular}{|c|c|}
\hline Sample & $\%$ \\
\hline \multicolumn{2}{|l|}{ Type of trip } \\
\hline Individual & 76 \\
\hline Organised group & 24 \\
\hline \multicolumn{2}{|l|}{ Transportation used } \\
\hline Own vehicle & 75 \\
\hline Bus & 24 \\
\hline Train & 1 \\
\hline \multicolumn{2}{|l|}{ Frequency } \\
\hline Once a year & 52 \\
\hline Two or more/year & 14 \\
\hline No frequency & 34 \\
\hline \multicolumn{2}{|l|}{ Duration of the visit } \\
\hline One day/transit & 34 \\
\hline A weekend & 34 \\
\hline$>2$ days & 32 \\
\hline \multicolumn{2}{|l|}{ People who accompany them } \\
\hline Family members & 51 \\
\hline Friends & 26 \\
\hline Other participants & 23 \\
\hline \multicolumn{2}{|l|}{ Other sights visited } \\
\hline Only religious & 73 \\
\hline Other/Non-religious & 27 \\
\hline \multicolumn{2}{|l|}{ Guided tour } \\
\hline Yes & 13 \\
\hline No & 87 \\
\hline \multicolumn{2}{|l|}{ Sources of information used for this kind of trips } \\
\hline Online/Mass Media & 48 \\
\hline Friends/family & 36 \\
\hline Church & 10 \\
\hline Agencies & 4 \\
\hline Brochures & 2 \\
\hline \multicolumn{2}{|l|}{ Reasons visiting the site } \\
\hline For the grave of Father Arsenie Boca & 82 \\
\hline For prayers (non-related to Father Arsenie Boca) & 11 \\
\hline From curiosity & 7 \\
\hline \multicolumn{2}{|c|}{$\begin{array}{l}\text { Degree of religiousness ( 1- non-religious - atheist ; } 4 \text { - very } \\
\text { religious) }\end{array}$} \\
\hline 1 & - \\
\hline 2 & 34 \\
\hline 3 & 53 \\
\hline 4 & 13 \\
\hline \multicolumn{2}{|c|}{ The concept of religious tourism in the vision of the visitor } \\
\hline A way of manifesting faith & 67 \\
\hline A way of enriching religious knowledge & 15 \\
\hline A way to value resources & 10 \\
\hline A economical activity & 8 \\
\hline \multicolumn{2}{|l|}{ The importance of Prislop Monastery for visitors } \\
\hline Representative & 45 \\
\hline Very important & 35 \\
\hline As important as others & 20 \\
\hline
\end{tabular}

Source: Primary research 
The most frequently used instrument for the assessment of religious motivation is Religious Orientation Scales (Allport \& Ross, 1967). The scales are based on Allport's conceptualisation of two religious orientations: extrinsic and intrinsic (Allport, 1966). An extrinsically-oriented person tends to use religion as a means of satisfying various needs, among which are: needs for security, solace, sociability, social status and self-justification. By contrast, an intrinsically-oriented person considers religion as an ultimate end in itself; religion is the main motivation of life. In addition, an important question is whether the structure of religious motivation may be explained in two dimensions. Kirkpatrick (1989) showed, using factor analysis, that items of the extrinsic religious orientation scale yield two factors: an extrinsic-social factor involving the use of religion as a means towards social gain; and an extrinsic-personal factor involving the use of religion as a means towards gaining positive emotional experiences, such as calm, comfort and joy (Stojković \& Miric, 2012).

Motivation can be defined as the driving force that is within all human beings; that is something that commits a person to a course of action (Mullins, 2009). Without motivation, pilgrims would not be able to achieve their spiritual goals. Drawing upon that body of knowledge can help us to understand the motivations underpinning pilgrimage, and, furthermore, to transfer that understanding to the context of pilgrimage management-at the planning stage, during the physical journey, and at the destination. Religious motivations are different from others. There are many competing theories of motivation, which aim to explain their nature. Motivation is a complex concept, and there is no universal or straightforward answer to the question of what motivates people (Blackwell, 2010).

To analyse the motivations and perceptions of the participants, it is important also to consider their degree of culture. This measurement can provide a complete picture of the population's access to different categories of tourist services, including religious and pilgrimage, and help assess differences in faith, religious beliefs, and the real reason for practising religious tourism. The degree of culture increases religiosity through a higher capacity to understand the religious phenomenon and an increased curiosity. It is essential to continually link the socio-demographic variables to the answers given, to outline a complete profile. When considering reasons for the visit, participants can be roughly classified into two categories, the ones that have a religious purpose and those who are curious. This subject highlighted that participants came predominantly for Father Arsenie Boca (82\%), knowing its history from various sources or previous trips they made here. All participants stand in line, whether they have a religious purpose or are curious, adopting the behaviour of those around them, passing by the Tomb of Father Arsenie Boca. Thus, we can conclude that people are informed about the phenomenon, and almost no participants came from curiosity without knowing about the subject (Table 2). Pictures illustrate the line formed by visitors to pray at the grave of Father Arsenie Boca that has significant power over visitors (Photo 2). 


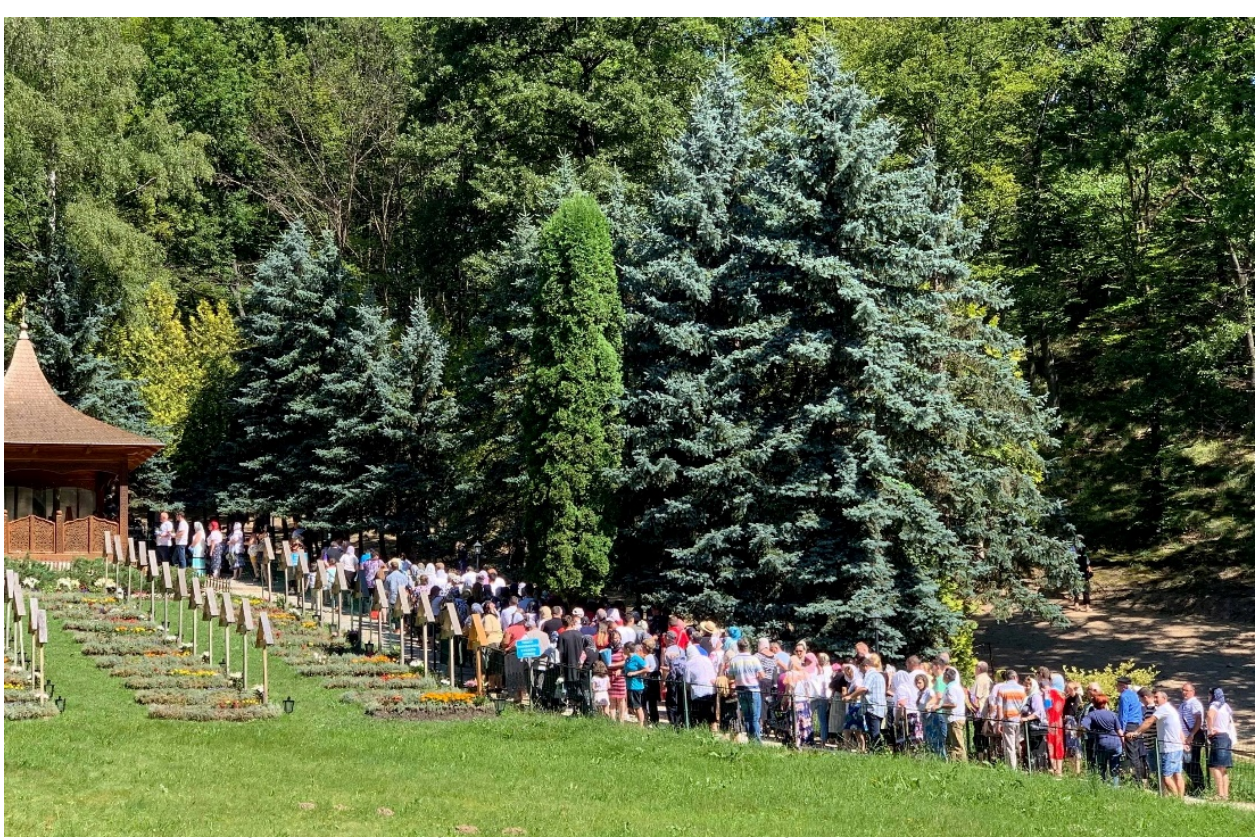

Photo 2. Visitors forming lines for praying to the grave of Father Arsenie Boca;

Author: Mădălina Giușcă, July 2019

\section{Faith}

It is often difficult to assess the faith of people, this being most of the timecorrelated with the religious practices undertaken, with the behaviour in the holy places and with the way of thinking. Pew Research Center published in 2018, a study related to the degree of religiosity of the countries. On this study, Romania has been classified as the first most religious out of 34 European countries, based on an overall combined index.

The index was created by combining four individual measures of religious observance - self-assessment of religion's importance in one's life, religious attendance, frequency of prayer, and belief in God.

An important question linked to this pattern was: the religiosity of the subjects. On a scale of 1 to 4 ( 1 being considered non-religious - atheist; and four very religious), it was found that no subject was considered atheists (Table 2). People avoided answering to this type of subject, being afraid that they will be judged. Most of them regardless of age and gender were included in the middle class (53\%), not being very religious but not devoid of faith either (Table 2) exceptions to this being the ones that came in organised groups by churches, where all respondents considered themselves very religious (14\%) by attending to all religious ceremonies in their hometown and praying daily.

From here it can be concluded that those who visit the monastery are religious people who manifest their faith in their own way even if this implies buying religious objects, drinking and taking home spring water from the monastery, praying at the grave of Father Arsenie Boca or throwing money in places with miraculous implications (Photo 3). 

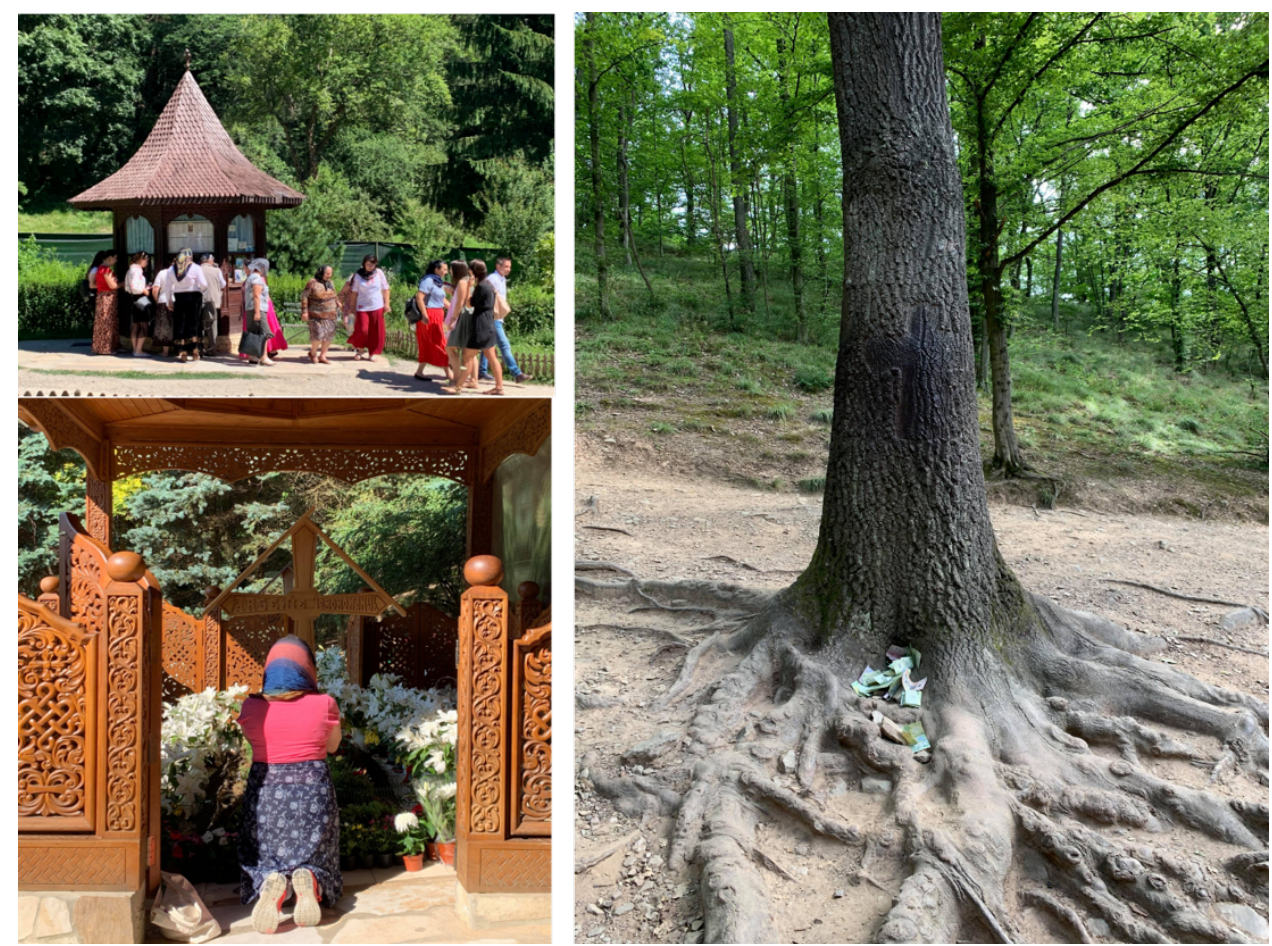

Photo 3. The manifestation of faith in visitors own style at Prislop Monastery Author: Mădălina Giușcă, July 2019

Religious visitors have a fixed route passing by all religious objectives or with a religious load within the monastery (at the cave, to the tree, the spring or trout) while ordinary visitors tend to ignore them, attracting their attention only when they see that it is crowded. By participating in the religious type of activities, faith can be manifested, and people can become believers, without an extension of this attitude in daily life. People need someone or something to believe in, to pray at, in this case - Father Arsenie Boca.

In the analysis of the concept of pilgrimage in the visitor's perspective, it was used the principle of synonymy in deducing the concept. The largest share $(60 \%)$ were the words in the lexical field of the word "faith" (faith, believers, religion, religiosity, prayers, peace, God, guidance, love, power, saints, closeness, wisdom); $20 \%$ of them thought of people, pilgrims, parishioners, large groups and $20 \%$ of religious travel, visiting, holy places, monasteries, churches. Their vision upon the concept of religious tourism was also investigated; most of the participants mentioned they consider it a way of manifesting faith (67\%). We can conclude that most subjects link the concept to religious beliefs, and very few attribute it to an economic / business activity (Table 2). To demonstrate a statement sustained by a previous study made in this direction, where Prislop Monastery received the highest score, is considered the most important shrine in Romania (Giusca et al., 2018), it was analysed the vision of participants regarding this aspect. The majority of them considered this holy place representative for Romania (45\%), 
which leads us to think that people appreciate this place of worship and consider it more important than the rest (Table 2).

\section{Modern pilgrimage}

The evolution of society towards modernity, in which science, technology, and time monopolise people, makes religious manifestations simplified practices, which no longer involve sacrifice and the idea of penance or total self-denial or the omnipotence of the sacred in people's lives. During this study at Prislop Monastery, were found both pilgrims (not traditional) and tourists from where we can conclude that a new type emerged, called - the modern pilgrim. This type has borrowed valences from both categories, but the constant is related to the belief in the divinity and also to comfort.

After analysing the results obtained, one can notice that the motivations, the degree of faith and perceptions are closely linked to socio-demographic variables. The practitioners are classified mostly according to their self-portrayed options, emerged from interviews as well a from field observations. Starting from the reasons of the visit and based on the theoretical conceptions about various types of pilgrimages/touristic trips discussed in the literature, the visitors have been classified into two categories: the pilgrim- who has a somewhat fixed profile, with religious beliefs, comes in organised groups joining other pilgrims, having solid religious principles and undertaking religious rituals.

The religious tourist comes with the family, strict with its transportation, having certain religious beliefs and manifestations, expressed in a particular manner. The profile of the pilgrim is outlined as an adult woman, over 30 years old, that comes from relatively small towns, with limited or higher studies, that is either single or married but predominantly with no children. Thru field observations and interviews, it must be pointed out that no men were seen participating in such kind of trips. However, today's pilgrims are not even close to what literature described over time; the only constant that remained is the pious attitude and devotion that is depicted.

The religious tourist is also drafted as a predominant adult woman but not limited to this, over 30 years that has a limited/higher level of education, single or married with children, which comes mainly from urban areas. The two profiles are different, but not limited to the characteristics. The conclusion was that the pilgrimage is close to today's religious tourism. Studies were also carried out on samples of visitors to the holy places and participants in religious events. They were placed on a scale, according to the objectives pursued, starting from "pilgrim devotees" to "traditional tourists" (Nolan \& Nolan, 1992).

Pilgrimage, in the traditional sense, no longer exists but has become a new type called pilgrimage tourism. This involves moving participants with their means of transportation, avoiding the formation of large groups, establishing an individual program of prayer, and visiting, depending on needs and possibilities. It can be considered that this is the modern type of religious pilgrimage. 


\section{Conclusions}

The objective of this study was to explore and identify the motivations as well as the perceptions of the visitors, outlining a proximate profile starting from the hypotheses that all participants have a particular relationship with divinity and also considering that each visitor has a more or less motivation related to religious practices. We also tried to identify those elements that share the visitors in the categories of pilgrims or tourists. However, there are great difficulties in making an exact distinction between the two categories since the motivations, practices, experiences and demographic profiles of visitors are different. Prislop Monastery was considered the perfect setting for this study, as is considered one of the most important religious edifices.

The results highlighted that many visitors came to the monastery following religious conviction, falling into the category of pilgrims, with some manifestations and beliefs. Others came out of pure curiosity or in need of meeting a life-changing miracle, falling into the practitioners of religious tourism category, but without many implications.

The image of the modern pilgrim, (a combination of a pilgrim and a tourist), in whose life the miracle took place has been reproduced. The monastery has visitors that come from different social backgrounds, united as participants in this form of tourism. The profile of the pilgrim/tourist could be outlined as a predominantly female person, with family, being rational and educated people with manifestations of faith, being in search of holiness to facilitate peace in life. Regardless of the competencies - pilgrim or tourist, the participants have faith in divinity and can fit into the discipline and state-imposed by a place of worship. Differentiate between the two categories, considering only the motivations and perceptions of the visitors, could be difficult, the subject will be in-depth analysed in further studies.

\section{References}

Allport, G.W. (1966), "The religious context of prejudice", Journal for the Scientific Study of Religion, vol. 5, p. 447-457.

Allport, G.W. and Ross, J. M. (1967), "Personal religious orientation and prejudice", Journal of Personality and Social Psychology, vol. 5, p. 432-443.

Blackwell, R. (2010), "Motivation for pilgrimage: using theory to explore motivations", Scripta Instituti Donneriani Aboensis, vol. 22, p. 24-37.

Cauc, I. (2004), Metodologia cercetarii sociologice,metode si tehnici de cercetare, Editura Fundatia Romaniei de Maine, Bucharest.

Cocean, P. (2004), Geografia turismului, Editura Focul Viu, Cluj-Napoca

Collins-Kreiner, N. and Kliot, N. (2000), "Pilgrimage tourism in the holy land: the behavioural characteristics of Christian pilgrims", GeoJournal 50, p. 55-67.

Crespi, V. and Planells, M. (2003), Patrimonio Cultural, Sintesis, Spain

Garfinkel, H. (1967), Studies in ethnomethodoly, Cliffs Prentice Hall, Englewood. 
Gheorghe, M. (2004), Religie si schimbare sociala in Romania, Editura Fundatiei Axis. Iasi.

Gheorghilaș, A. (2014), Geografa Turismului - Metode de analiză in turism, Editura Universitară, Bucharest.

Gillet, O. (2001), Religie si nationalism. Ideologia Bisericii Ortodoxe Romane sub regimul communist, Compania Altfel, Bucharest.

Giușcă, M., Gheorghilaș, A. and Dumitrache, L. (2018), "Assessment of the religious-tourism potential in Romania", Human Geographies - Journal of Studies and Research in Human Geography, vol. 12, no. 2, p. 225-237.

Hackett, C., Murphy, C. and McClendon, D. (2016), The gender gap in religion around the world, Pew Research Center, Washington, DC.

Ielenicz, M, and Comănescu, L. (2006), Potential turistic, Editura Universitara, Bucharest.

Institutul National de Statistica (2013), Rezultatele recensamantului populatiei din anul 2011, Bucharest

Kirkpatrick, L. A. (1989), "A psychometric analysis of the Allport-Ross and Feagin measures of intrinsic-extrinsic religious orientation" n D.O. Moberg and M.L. Lynn (eds.), Research in the social scientific study of religion (vol. 1), CT: JAI Press, Greenwich

MacCannell, D. (1976), The Tourist: A New Theory of the Leisure Class, Schocken Books, New York.

Martinez-Cardenas, R., (2010), "Tourisme spirituel. Le mystique comme patrimoine touristique" in J.M Breton (ed.) Patrimoine, tourisme, environnement et développement durable (Europe-Afrique-Carabe-Amériques-Asie-Océanie), Karthala Crejeta.

Mullins, L. (2009), Management and Organisational Behaviour, Financial Times Prentice Hall, Harlow.

Nolan, M.L. and Nolan, S. (1992), Christian Pilgrimage in Modern Western Europe, University of North Carolina Press.

Noppen, L. and Morisset, L.K., (2003), "Le tourisme religieux et le patrimoine", Téoros, vol. 22, no. 2, p. 69-70, 10 December 2019, shorturl.at/sxzK2.

Pew Research Center, (2018), How Religious is your country, Washington DC, 11 December 2019, shorturl.at/dvPV4.

Reader, I. and Walter, T. (eds.) (1993), Pilgrimage in Popular Culture, Palgrave Macmillan, London, UK.

Reisinger, Y. (1994), "Tourist - host contact as a part of cultural tourism", World Leisure E Recreation, vol. 36, no. 2.

Richards, G. (2018), "Cultural tourism: A review of recent research and trends", Journal of Hospitality and Tourism Management, vol. 36, p. 12-21.

Richards, G. (ed.) (2007), Cultural tourism: Global and local perspectives, Haworth Press, Binghamton.

Rinschede, G. (1992), "Forms of Religious Tourism", Annals of Tourism Research, vol. 19, p. 51-62. 
Schaefer, C.A. and Gorsuch, R.L. (1991), "Psychological adjustment and religiousness: The multivariate belief-motivation theory of religiousness", Journal for the Scientific Study of Religion, vol. 30, p. 448-461.

Snak, O. (1976), Economia și organizarea turismului, Editura Sport-Turism, Bucharest.

Stark, R. (2002), "Physiology and faith: Addressing the "Universal" gender difference in religious", Journal for the Scientific of Religion, vol. 41, no. 3, no. 495507.

Stojković, I. and Mirić, J. (2012), "Construction of a Religious Motivation Questionnaire", PSIHOLOGIJA, vol. 45, no. 2, p. 155-170.

Tomasi, L. (2002), "Homo Viator: From Pilgrimage to Religious Tourism via the Journey" in W.H. Swatos, Jr. and L. Tomasi (eds.), From Medieval Pilgrimage to Religious Tourism: The Social and Cultural Economics of Piety, Praeger Publishers, Westport.

Trzebiatowska, M. and Bruce, S. (2012), Why are women more religious than men?, Oxford University Press, United Kingdom.

Turner, V. (1973), "The Center out There: Pilgrim's Goal", History of Religions, vol. 12, no. 3, p. 198-230.

Turner, V. and Turner, E. (1978), Image and Pilgrimage in Christian Culture: Anthropological Perspective, Basil Blackwell, Oxford.

Voicu, M. (2007), Romania religioasa, pe valul european sau in urma lui?, Institutul European, Iasi.

Walter, T. and Davie, G. (1998), "The religion of women in the Modern West", British Journal of Sociology, vol. 49, no. 4, no. 640-60.

Whelan, T. (1991), Nature tourism. Managing for the environment, Island Press, Washington DC.

WIN-Gallup International (2012), Global Index of Religiosity and Atheism, 12 March 2019, shorturl.at/bJLY5. 